\title{
Genetic Diversity Among Ophiosphaerella agrostis Strains Causing Dead Spot in Creeping Bentgrass
}

John E. Kaminski and Peter H. Dernoeden, Department of Natural Resource Sciences and Landscape Architecture, University of Maryland, College Park 20742; and Sue Mischke and Nichole R. O'Neill, USDA-ARS, Beltsville, MD 20705

\begin{abstract}
Kaminski, J. E., Dernoeden, P. H., Mischke, S., and O’Neill, N. R. 2006. Genetic diversity among Ophiosphaerella agrostis strains causing dead spot in creeping bentgrass. Plant Dis. 90:146-154

Dead spot (Ophiosphaerella agrostis) is a relatively new disease of young creeping bentgrass and hybrid bermudagrass putting greens in the United States. Little is known about the biology or genetic diversity of the pathogen. $O$. agrostis is unusual in that it produces prodigious numbers of pseudothecia in the field throughout the summer months and has no known asexual state. A total of 77 O. agrostis isolates were collected from 21 different bentgrass putting greens and one hybrid bermudagrass green in 11 states. DNA fingerprint analysis revealed that 78 out of 97 markers were polymorphic ( $80.4 \%)$, providing 57 unique profiles. Genetic variation of $O$. agrostis was diverse, and isolates separated into three distinct clades with $\geq 69 \%$ similarity. Analysis of molecular variance indicated that the geographic origins of the isolates and the ability to produce pseudothecia were the best indicators for genetic similarity among $O$. agrostis isolates. Colony color varied among the isolates, but generally was similar for isolates residing within two clades (B and C). Colony color of isolates within clade A appeared to be a mixture of the colony colors exhibited by clades B and C. Isolates examined within each clade generally had varying levels of pseudothecia production and varying colony colors when grown on PDA. Although $O$. agrostis is a homothallic species, it is unclear if outcrossing among strains occurs.
\end{abstract}

Additional keywords: colonial bentgrass, phylogeny, sexual reproduction, velvet bentgrass

Dead spot is a new disease of young creeping bentgrass (Agrostis stolonifera L.) putting greens in the United States. The disease is incited by Ophiosphaerella agrostis Dernoeden, M.P.S. Câmara, N.R. O'Neill, van Berkum, et M.E. Palm, a previously undescribed pathogen that first was isolated in 1998 from a golf course in Maryland $(1,3)$. In the same year, the disease was confirmed on creeping bentgrass putting greens in five states. Since 1998, $O$. agrostis has been found in at least 13 states and has been isolated from several additional turfgrass species, including hybrid bermudagrass (Cynodon dactylon (L.) Pers. $\times$ C. transvaalensis Burtt-Davy) and colonial (A. capillaris L.) and velvet (A. canina L.) bentgrasses $(1,11,14)$.

Dead spot generally appears within 1 to 2 years following establishment of creeping bentgrass putting greens. The disease also may occur on renovated putting sur-

Corresponding author: John E. Kaminski E-mail: john.kaminski@uconn.edu

J. E. Kaminski is now Assistant Professor, Department of Plant Science, University of Connecticut, Storrs.

Accepted for publication 23 August 2005.

DOI: 10.1094/PD-90-0146

(C) 2006 The American Phytopathological Society faces following fumigation with methyl bromide. In the mid-Atlantic region of the United States, disease symptoms may appear as early as May, and disease activity often peaks between July and August (10). Initially, the disease appears as small, copper or reddish-brown spots approximately 1 to $2 \mathrm{~cm}$ in diameter that may increase to approximately 6 to $8 \mathrm{~cm}$ throughout the summer months. Once infection occurs, turfgrass in the center of dead spots dies and pits or depressions often form which adversely affect the putting surface. Regrowth of bentgrass in infected spots is slow, and dead spots often remain present throughout the winter until bentgrass growth resumes in the spring.

Other species within the genus Ophiosphaerella $(O$. herpotricha J. Walker, $O$. korrae Walker \& Smith (synonym Leptosphaeria korrae), and $O$. narmari Walker \& Smith (synonym L. narmari)) cause various turfgrass diseases $(2,4,5,15,24,26$, 31,32). The aforementioned Ophiosphaerella spp., however, have not been reported to infect creeping bentgrass.

Unlike other Ophiosphaerella spp. found in association with turfgrasses, the production of pseudothecia by $O$. agrostis is common. Field observations revealed that $O$. agrostis is capable of producing prodigious numbers of pseudothecia in necrotic leaf, sheath, and stolon tissues $(3,11)$. Growth chamber studies confirmed that pseudothecia development can occur within 4 days and that mature ascospores may be produced in as little as 1 week when subjected to a range of temperatures (13 to $28^{\circ} \mathrm{C}$ ) and constant light (12). In a Maryland field study, pseudothecia developed in the greatest numbers during the summer months (June to August), but occasionally developed as late as September (10). Additionally, immature ascospores were found in small numbers within pseudothecia throughout the winter (10). The pathogen's ability to proliferate sexually during the summer months increases the chance for genetic recombination. The capability of $O$. agrostis to undergo numerous meiotic cycles in a single season ultimately may lead to increased pathogen fitness due to a more diverse population.

Genetic analyses, based on amplified fragment length polymorphism (AFLP) fingerprinting of $O$. agrostis isolates collected in 1998, revealed an $87 \%$ or greater similarity among isolates from five different states (1). Previous studies revealed that a single isolate $(\mathrm{OpOH}-1)$ exhibited differences in colony color, sequence within the internal transcribed spacer (ITS) 2 region of ribosomal DNA, and fungicide sensitivity when compared with the type species $(1,9)$. Unlike the rose-quartz or pink colony color of most isolates collected in 1998, O. agrostis isolate OpOH-1 exhibited white to olive-gray mycelia when grown on potato dextrose agar (PDA) at $25^{\circ} \mathrm{C}(1,12)$. Although within the range $(75$ to $150 \mu \mathrm{m})$ reported by Câmara et al. (1) in the original description of $O$. agrostis, ascospores of isolate $\mathrm{OpOH}-1$ produced on PDA were shorter (68 to 98 $\mu \mathrm{m})$ and had fewer septa (6 to 8) than most other isolates (9). Additionally, rDNA sequencing of three $O$. agrostis isolates revealed a single base pair (bp) insertion of thymine nested between a cytosine and a five-thymine repeat in two different locations of the ITS2 region in $\mathrm{OpOH}-1$ (1). Finally, in vitro experiments indicated reduced sensitivity of the isolate $\mathrm{OpOH}-1$ to the fungicide iprodione (3-(3,5dichlorophenyl)- $N$-(1-methylethyl)-2,4-dioxo-1-imidazolidinecarboxamide) (9).

Additional AFLP fingerprinting from a larger population is needed to elucidate genetic diversity within $O$. agrostis. Since the initial description of the pathogen, additional isolates exhibiting varying colony characteristics have been collected 
Table 1. Isolate designation, cultivar affected, collection location, date received, collector, and color of 77 Ophiosphaerella agrostis isolates from the United States

\begin{tabular}{|c|c|c|c|c|c|}
\hline Isolate $^{\mathbf{a}}$ & Host cultivar ${ }^{b}$ & City, state & Date received & Iso. $\mathbf{p t}^{\mathbf{c}}$ & Color $^{d}$ \\
\hline OpIL-1 $1^{\text {RK }}$ & SR 1119 & Glencoe, IL & 18 Dec. 1998 & ht & Rose-quartz \\
\hline OpIL-2 $2^{\text {RK }}$ & SR1119 + L-93 + Providence & Golf, IL & 8 Dec. 2000 & ht & Rose-quartz \\
\hline OpIL-3 $3^{\text {RK }}$ & L-93 & Olympia Fields, IL & 8 Dec. 2000 & ht & Rose-quartz \\
\hline OpIL-4 ${ }^{\mathrm{RK}}$ & L-93 & Park Ridge, IL & 1 Aug. 2002 & ht & Rose-quartz \\
\hline OpIL-5 $5^{\text {RK }}$ & L-93 & Park Ridge, IL & 1 Aug. 2002 & ht & Rose-quartz \\
\hline OpMA-1 & L-93 & West Bridgewater, MA & 27 July 2002 & lf & Gray/buff \\
\hline OpMA-3 & Penn A-4 & Hingham, MA & Summer 2003 & ht & Gray/buff \\
\hline OpMA-4 & Penn A-4 & Hingham, MA & Summer 2003 & ht & Gray/buff \\
\hline OpMI-1 & Providence & East Tawas, MI & 29 Sept. 2000 & lf & Rose-quartz \\
\hline OpMI-2 & Providence & East Tawas, MI & 29 Sept. 2000 & If & Rose-quartz \\
\hline OpNC- $1^{\mathrm{HW}}$ & Penncross & Laurinburg, NC & 11 Aug. 2000 & ht & Gray \\
\hline $\mathrm{OACS}^{\mathrm{BC}}$ & L-93 & Millstown, NJ & Summer 2001 & ht & Gray/buff \\
\hline OpNJ-4 & L-93 & New Brunswick, NJ & 27 July 1999 & ss & Gray/buff \\
\hline OpNJ-5 & Penn A-4 & Northfield, NJ & 28 Sept. 2000 & ht & Gray/buff \\
\hline OpNJ-6 & Penn A-4 & Northfield, NJ & 28 Sept. 2000 & ht & Gray \\
\hline OpNY-1 & L-93 & Altamont, NY & 11 Aug. 2000 & ht & Gray/buff \\
\hline OpOH-1 & L-93 & Chardon, $\mathrm{OH}$ & 21 Oct. 1998 & ht & Gray/buff \\
\hline OpPA-1 & Crenshaw + Southshore & Avondale, PA & 23 Dec. 1998 & ss & Gray/buff \\
\hline OpPA-4 & L-93 & Honeybrook, PA & 2 Nov. 1999 & lf & Gray/buff \\
\hline OpPA-6 & SR1120 + L-93 + Providence & Avondale, PA & 8 Mar. 2000 & sa & Rose quartz \\
\hline OpPA-8 & L-93 & Honeybrook, PA & 15 Aug. 2000 & ht & Gray/buff \\
\hline OpVA-1 & Pennlinks & Sterling, VA & 10 Sept. 1998 & ss & Rose-quartz \\
\hline OpVA-3 & Penn A-4 & Virginia Beach, VA & 15 June 2002 & ht & Rose-quartz \\
\hline OpVA-4 & Penn A-4 & Virginia Beach, VA & 15 June 2002 & ht & Rose-quartz \\
\hline$\# 121^{\mathrm{NT}}$ & 'Champion' bermudagrass & College Station, TX & Spring 1998 & ht & Rose quartz \\
\hline $\mathrm{HCC} 1$ & L-93 + Crenshaw & Hunt Valley, MD & 21 Oct. 1998 & lf & Rose quartz \\
\hline $\mathrm{HCC} 2$ & L-93 + Crenshaw & Hunt Valley, MD & 21 Oct. 1998 & ss & Rose quartz \\
\hline OpMD-3 & Penncross & Ocean City, MD & 16 Oct. 1998 & ss & Rose-quartz \\
\hline OpMD-4 & L-93 + Crenshaw & Upper Marlboro, MD & 26 Oct. 1998 & st & Rose-quartz \\
\hline OpMD-5 & L-93 + Crenshaw & Aberdeen, MD & 15 Oct. 1998 & sa & Rose-quartz \\
\hline PBD1 & Penn-G2 & Urbana, MD & 21 Aug. 1998 & ss & Rose-quartz \\
\hline PBD2 & Penn-G2 & Urbana, MD & 21 Aug. 1998 & st & Rose-quartz \\
\hline OpMD-9 & Providence & Silver Spring, MD & 13 Nov. 1998 & ss & Rose-quartz \\
\hline OpMD-10 & L-93 + Crenshaw & Upper Marlboro, MD & 26 Oct. 1998 & ss & Beige/buff \\
\hline OpMD-12 & L-93 & Havre de Grace, MD & 14 Aug. 1999 & $\mathrm{sa}$ & Gray \\
\hline OpMD-13 & 'Bardot' colonial & College Park, MD & 8 Sept. 2000 & lf & Rose-quartz \\
\hline OpMD-14 & L-93 & Joppa, MD & 26 July 2001 & st & Rose-quartz \\
\hline OpMD-15 & L-93 & Joppa, MD & 26 July 2001 & lf & Rose-quartz \\
\hline OpMD-16 & Penn A-4 & Laytonsville, MD & 30 Aug. 2001 & lf & Rose-quartz \\
\hline OpMD-17 & Providence & College Park, MD & 26 Oct. 2001 & Ss & Rose-quartz \\
\hline OpMD-18 & Providence & College Park, MD & 9 Nov. 2001 & st & Rose-quartz \\
\hline OpMD-19 & Penncross & Ocean City, MD & 16 Oct. 1998 & If & Rose-quartz \\
\hline OpMD-21 & L-93 & College Park, MD & 20 June 2002 & ht & Rose-quartz \\
\hline OpMD-22 & L-93 & College Park, MD & 20 June 2002 & ht & Rose-quartz \\
\hline OpMD-23 & L-93 & College Park, MD & 20 June 2002 & ht & Rose-quartz \\
\hline OpMD-26 & L-93 & College Park, MD & 28 Oct. 2002 & ht & Rose-quartz \\
\hline OpMD-27 & L-93 & College Park, MD & 28 Oct. 2002 & ht & Rose-quartz \\
\hline OpMD-29 & L-93 & College Park, MD & 25 Nov. 2002 & ht & Rose-quartz \\
\hline OpMD-34 & L-93 & College Park, MD & 25 Nov. 2002 & ht & Rose-quartz \\
\hline OpMD-36 & 'Bavaria' velvet & College Park, MD & 25 Nov. 2002 & ht & Rose-quartz \\
\hline OpMD-40 & L-93 & College Park, MD & 25 Nov. 2002 & ht & Rose-quartz \\
\hline OpMD-42 & L-93 & College Park, MD & 28 Jan. 2003 & ht & Rose-quartz \\
\hline OpMD-43 & L-93 & College Park, MD & 26 Mar. 2003 & ht & Rose-quartz \\
\hline OpMD-44 & L-93 & College Park, MD & 26 June 2003 & ht & Gray/buff \\
\hline OpMD-45 & L-93 & College Park, MD & 26 June 2003 & ht & Gray/buff \\
\hline OpMD-46 & L-93 & College Park, MD & 26 June 2003 & ht & Gray/buff \\
\hline OpMD-47 & L-93 & College Park, MD & 26 June 2003 & ht & Gray/buff \\
\hline OpMD-48 & L-93 & College Park, MD & 1 Oct. 2003 & ht & Rose-quartz \\
\hline OpMD-49 & L-93 & College Park, MD & 1 Oct. 2003 & ht & Rose-quartz \\
\hline OpMD-50 & L-93 & College Park, MD & 1 Oct. 2003 & ht & Rose-quartz \\
\hline OpMD-51 & L-93 & College Park, MD & 1 Oct. 2003 & ht & Gray/buff \\
\hline OpMD-52 & L-93 & College Park, MD & 1 Oct. 2003 & ht & Rose-quartz \\
\hline OpMD-53 & L-93 & College Park, MD & 1 Oct. 2003 & ht & Gray/buff \\
\hline OpMD-54 & L-93 & College Park, MD & 1 Oct. 2003 & ht & Rose-quartz \\
\hline OpMD-55 & L-93 & College Park, MD & 1 Oct. 2003 & ht & Gray/buff \\
\hline OpMD-56 & L-93 & College Park, MD & 1 Oct. 2003 & ht & Rose-quartz \\
\hline OpMD-57 & L-93 & College Park, MD & 1 Oct. 2003 & ht & Rose-quartz \\
\hline OpMD-58 & L-93 & College Park, MD & 1 Oct. 2003 & ht & Rose-quartz \\
\hline OpMD-59 & L-93 & College Park, MD & 1 Oct. 2003 & ht & Rose-quartz \\
\hline OpMD-60 & L-93 & College Park, MD & 1 Oct. 2003 & ht & Rose-quartz \\
\hline OpMD-61 & L-93 & College Park, MD & 1 Oct. 2003 & ht & Gray/buff \\
\hline OpMD-62 & L-93 & College Park, MD & 1 Oct. 2003 & ht & Gray/buff \\
\hline OpMD-63 & L-93 & College Park, MD & 1 Oct. 2003 & ht & Rose-quartz \\
\hline OpMD-64 & L-93 & College Park, MD & 1 Oct. 2003 & ht & Rose-quartz \\
\hline OpMD-65 & L-93 & College Park, MD & 1 Oct. 2003 & ht & Rose-quartz \\
\hline OpMD-66 & L-93 & College Park, MD & 1 Oct. 2003 & ht & Rose-quartz \\
\hline OpMD-67 & L-93 & College Park, MD & 1 Oct. 2003 & ht & Rose-quartz \\
\hline
\end{tabular}

a Isolates were collected by author unless otherwise noted as follows: NT = Ned Tisserat, HW = Henry Wetzel, BC = Bruce Clarke, and RK = Randy Kane.

b All cultivars listed are creeping bentgrass unless otherwise noted.

c Isolation of $O$. agrostis were as follows: ht = hyphal tip, lf = leaf, sa = single ascocarp, ss = single ascospore, and st $=$ stolon.

${ }^{\mathrm{d}}$ Colony color was assessed after 10 days growth on potato dextrose agar incubated at $25^{\circ} \mathrm{C}$ in constant darkness. 
from a broader geographic distribution and host range. The goal of this study was to identify variation within $O$. agrostis based on morphological, biological, and molecular characters. The specific objectives of this study were to: (i) identify genetic diversity among $O$. agrostis isolates using fluorescent AFLP DNA fingerprinting; (ii) re-examine colony color and other characteristics that may distinguish isolates; and (iii) determine individual isolates' rate of pseudothecia production.

\section{MATERIALS AND METHODS}

Fungal isolates. Between 1998 and 2003, 77 O. agrostis isolates were collected from 21 different creeping bentgrass or hybrid bermudagrass putting greens in 11 states. Isolates from creeping bentgrass were collected from Maryland (MD) $(n=$ 52), Virginia (VA) $(n=3)$, Ohio $(\mathrm{OH})(n=$ $1)$, New Jersey (NJ) $(n=4)$, Pennsylvania (PA) $(n=4)$, Massachusetts (MA) $(n=3)$, New York (NY) $(n=1)$, Illinois (IL) $(n=$ $5)$, North Carolina (NC) $(n=1)$, and Michigan (MI) $(n=2)$. Additionally, a single isolate from hybrid bermudagrass was collected from a research putting green at Texas A\&M University in College Station, Texas (TX). The isolates were grown on PDA in petri dishes in a dark incubator maintained at $25^{\circ} \mathrm{C}$ for 10 days. Colony morphology of all isolates was described and photographed (Table 1). Prior to DNA extraction, isolates were stored in potato dextrose broth (PDB) or on PDA slants at $4^{\circ} \mathrm{C}$ or at $-20^{\circ} \mathrm{C}$ in a $20 \%$ glycerol solution.

DNA isolation. DNA was extracted from fungal cultures grown at room temperature for 7 to 10 days in $100 \mathrm{ml}$ of PDB (24 g liter $^{-1}$ ) on a shaker table (LabLine Orbit Shaker, Lab-Line Instruments Inc., Melrose, IL) set to $90 \mathrm{rpm}$. Cultures were filtered through Whatman no. 1 filter paper, rinsed in distilled, deionized $\mathrm{H}_{2} \mathrm{O}$ $\left(\mathrm{ddH}_{2} \mathrm{O}\right)$ and lyophilized in a Freezemobile 6 (The VirTis Company, Gardiner, NY) for 24 to $48 \mathrm{~h}$. Freeze-dried mycelial mats were stored at $-20^{\circ} \mathrm{C}$ or immediately prepared for DNA extraction. Approximately 20 to $30 \mathrm{mg}$ of freeze-dried mycelia were placed in a 1.5-ml microcentrifuge tube
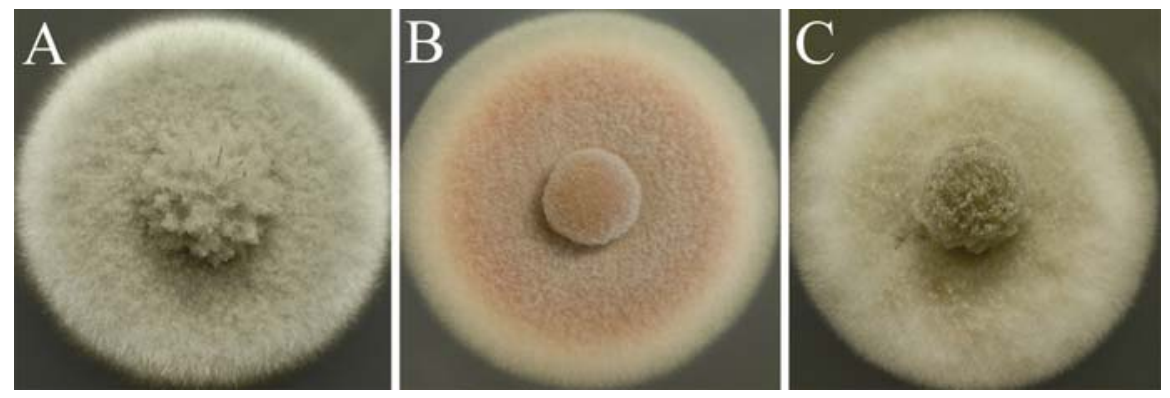

Fig. 1. Typical variation in colony color and morphology of Ophiosphaerella agrostis isolates separating into each of three clades determined by amplified fragment length polymorphism DNA fingerprinting. Isolates shown include OpNC-1, OpMD-14, and OpPA-8 and represent clades A, B, and C, respectively.

and ground into a fine powder using a micropestle. Liquid nitrogen occasionally was used to aid in the grinding process.

Total genomic DNA was extracted using Qiagen DNeasy Plant Mini Kit (Qiagen Inc., Valencia, CA). A total of $400 \mu \mathrm{l}$ of Buffer AP1 and $4 \mu \mathrm{l}$ of RNase A stock solution was added to pulverized mycelia and vortexed until thoroughly mixed. To lyse cells, the mixture then was incubated for $10 \mathrm{~min}$ at $65^{\circ} \mathrm{C}$, mixing 2 to 3 times during incubation. To precipitate proteins and polysaccharides, $130 \mu \mathrm{l}$ of Buffer AP2 was added to the lysate, which was incubated on ice for $5 \mathrm{~min}$. The tubes then were centrifuged for $5 \mathrm{~min}$ at $16,000 \mathrm{rpm}$ and the lysate was added to the supplied QIAshredder column. The material then was centrifuged for $2 \mathrm{~min}$ at 16,000 rpm. The eluate material was placed in a $1.5-\mathrm{ml}$ microcentrifuge tube, and $675 \mu \mathrm{l}$ of Buffer AP3/E was added. DNA was separated from the mixture by centrifugation in a DNeasy mini-spin column. Buffer AW $(500 \mu \mathrm{l})$ was added to the mini-spin column and centrifuged for $1 \mathrm{~min}$ at 8,000 rpm. An additional $500 \mu \mathrm{l}$ of Buffer AW was added, and the spin column membrane was dried by centrifuging for $2 \mathrm{~min}$ at $16,000 \mathrm{rpm}$. For the final step, $50 \mu \mathrm{l}$ of the preheated $\left(65^{\circ} \mathrm{C}\right)$ elution buffer was added, the column centrifuged for $1 \mathrm{~min}$ at 8,000 $\mathrm{rpm}$, and the step repeated. Isolated DNA was used immediately or stored at $-20^{\circ} \mathrm{C}$ prior to AFLP analyses.

AFLP analyses. Fluorescent AFLP with automated capillary electrophoresis (fAFLPCE) was used to examine 77 O. agrostis isolates. DNA fragments were amplified by a multi-step procedure, originally proposed by Vos et al. (28) with modifications developed by Viji et al. (27). O. agrostis template DNA $(5.5 \mu \mathrm{l})$ was digested with EcoRI and MseI (New England BioLabs, Beverly, MA) and ligated to commercial EcoRI and MseI oligonucleotide adapters (Applied Biosystems, Foster City, CA) and incubated overnight at room temperature. The entire procedure was described previously $(22,23,27)$. Preselective AFLP primers (EcoRI and MseI) and AFLP core mix (Applied Biosystems) were used for the preselective amplification of the restricted

148 Plant Disease /Vol. 90 No. 2 and ligated fragments. The mixture was subjected to amplification at $94^{\circ} \mathrm{C}$ for 3 min followed by 20 cycles of the following profile: $94^{\circ} \mathrm{C}$ for $20 \mathrm{~s}, 56^{\circ} \mathrm{C}$ for $30 \mathrm{~s}$, and $72^{\circ} \mathrm{C}$ for 2 min (GeneAmp 9700 PCR system, Applied Biosystems). The amplified product was then held at $60^{\circ} \mathrm{C}$ for 30 min. Selective amplification utilized a fluorescent WellRED D4 dye-labeled phosphoramidite added to the $5^{\prime}$ end of an EcoRI+AG primer (Invitrogen Life Technologies, Carlsbad, CA). A custom $M s e \mathrm{I}+\mathrm{C}$ primer without fluorescence was used in combination with the aforementioned labeled primer (Qiagen). The preselective amplification products were diluted as described previously (22) and used for selective amplification. Labeled EcoRI primer $(0.05 \mu \mathrm{M})$ and the unlabeled MseI primer $(0.10 \mu \mathrm{M})$ were added to the template and the mixture was subjected to a thermocycling profile of $94^{\circ} \mathrm{C}$ for $2 \mathrm{~min}$, followed by 10 cycles of $94^{\circ} \mathrm{C}$ for $20 \mathrm{~s}$, $1^{\circ} \mathrm{C}$ per cycle reduction of annealing temperature from $66^{\circ} \mathrm{C}$ to $57^{\circ} \mathrm{C}$ held for $30 \mathrm{~s}$ and $72^{\circ} \mathrm{C}$ for $2 \mathrm{~min}$. This was followed by 25 cycles of $94^{\circ} \mathrm{C}$ for $20 \mathrm{~s}, 56^{\circ} \mathrm{C}$ for $30 \mathrm{~s}$, and $72^{\circ} \mathrm{C}$ for $2 \mathrm{~min}$. The products were then held at $60^{\circ} \mathrm{C}$ for $30 \mathrm{~min}$ to complete the reaction.

The final amplified product was diluted $1: 30 \quad(\mathrm{vol} / \mathrm{vol})$ in commercial Sample Loading Solution (Beckman-Coulter, Fullerton, CA), which included $1 \%$ (vol/vol) Beckman-Coulter 400 bp DNA size standards. Fragment separation and detection were performed by capillary electrophoresis using a genetic analysis system (CEQ 8000 , Beckman-Coulter) and data analyzed using CEQ 8000 fragment analysis software and methods previously described (27). For AFLP analysis, maximum bin width was 1.0 nucleotide. Peaks that clearly were present, but not recognized by the automated scoring, were added manually. Minor peaks that appeared in most or all samples, but were recognized sporadically by the software, were manually removed from the analyses. Samples were scored as " 1 " if a fragment was present and " 0 " if absent. The bin was scored as " 1 " in cases where two fragments were present.

All data, including nonpolymorphic bins, were imported into the multivariate data analysis program, NTSYSpc, version 2.1 (Exeter Software, Setauket, NY). A similarity matrix based on simple matching coefficients was generated using the SimQual module, and the module SAHN was used to perform hierarchical clustering using an unweighted pair-group method with arithmetic mean (UPGMA) (25). The tree matrix generated by SAHN was converted into a dendrogram using the module Tree Plot. Grouping of isolates into distinct clades was confirmed using the neighbor joining (NJ) method (20).

Analysis of molecular variance (AMOVA) in GenALEX was calculated to determine 
genetic similarity among isolates based on certain characteristics, including isolate color, geographic state and region, and pseudothecia production (17). The AMOVA can be used to determine if a specific observable characteristic would predict genetic similarity. Within each categorical class, the AMOVA compares the genetic distances among individuals sharing similar characteristics to the genetic distance among individual isolates outside of their type. Pair-wise genetic distances for AMOVA were calculated as described by Huff et al. (8) as $D=n[1-$ $\left(2 n_{x y} / 2 n\right)$ ], where $n_{x y}=$ number of shared bands, and $n=$ total banding positions. The AMOVA partitions genetic distance variance among and within characteristic classes, and tests of significance were calculated using a bootstrap with 999 replications. Greater genetic variation of iso- lates among classes, when compared with genetic variation within a class, indicates genetic similarity. Only categorical classes containing two or more isolates were included in the AMOVA analyses.

Pseudothecia production. The ability of an $O$. agrostis isolate to produce pseudothecia and its rate of pseudothecia development were used as a determinant of each isolate's ability to reproduce sexually. Pseudothecia were produced using the method developed by Kaminski et al. (12). Briefly, a mix of tall fescue (Festuca arundinacea Schreb.) seed and wheat (Triticum aestivum L.) bran $(1: 1 \mathrm{vol} / \mathrm{vol})$ was prepared by soaking tall fescue seeds in tap water overnight. Seeds then were rinsed three times and mixed with wheat bran (vol/vol), placed in 250-ml flasks, and autoclaved for $1 \mathrm{~h}$ on two consecutive days. Mycelia from the edge of a colony actively growing on PDA were removed and placed on the surface of the cooled seed/bran mix. Flasks then were incubated in a growth chamber under constant light $\left(88 \mu \mathrm{mol} \cdot \mathrm{m}^{-2} \cdot \mathrm{s}^{-1}\right.$ from four $\mathrm{F} 20 \mathrm{~T} 12 / \mathrm{CW}$, 20-watt bulbs; Philips Lighting, Somerset, $\mathrm{NJ}$ ) at $25^{\circ} \mathrm{C}$ for 21 days. Inoculum was mixed every 1 to 3 days to promote aeration and to allow mycelia to become evenly distributed throughout the medium. After 21 days of incubation, approximately $0.20 \mathrm{~g}$ of the infested mix was placed on sterile, moist filter paper (Qualitative 415, VWR Scientific, West Chester, PA) in a 60 by $15 \mathrm{~mm}$ petri dish (VWR Scientific). Petri dishes containing infested media were placed in the aforementioned growth chamber. The mixture and filter paper were kept moist throughout the study by adding $1 \mathrm{ml}$ of $\mathrm{ddH}_{2} \mathrm{O}$ periodically to dried filter paper. Every other day, seeds were rated
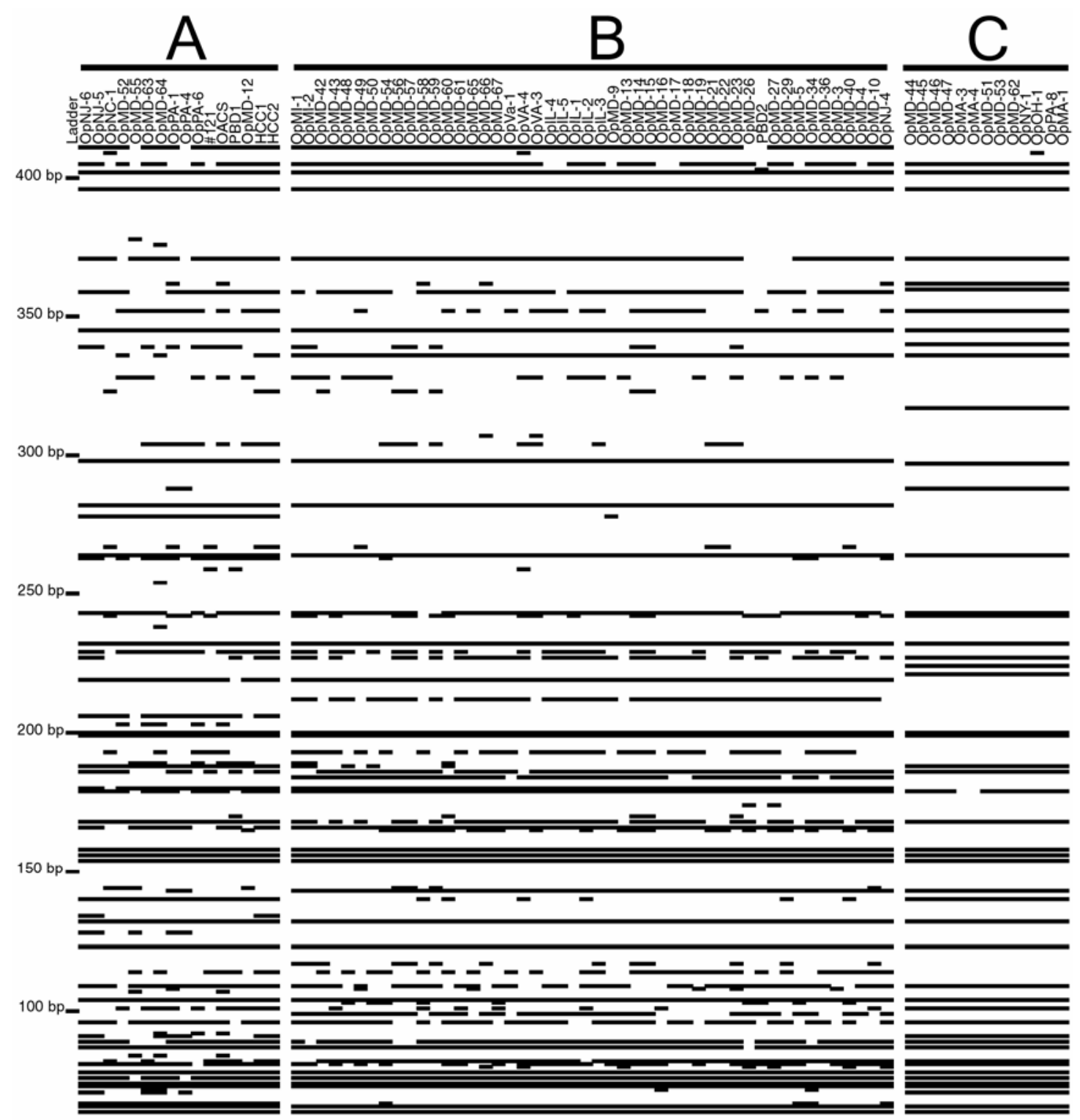

$50 \mathrm{bp}=$

Fig. 2. DNA fragment banding pattern of 77 Ophiosphaerella agrostis isolates after fluorescent amplified fragment length polymorphism analysis with automated capillary electrophoresis. 
visually for abundance of pseudothecia using a previously described (12) 0 to 5 linear scale where $0=$ none, $3=11$ to 15 , and $5=$ more than 21 pseudothecia with necks partially embedded in tall fescue seed. The experiment was arranged in a randomized complete block with three replications (growth chambers) and the entire experiment performed twice. Within each growth chamber, each isolate was replicated twice and mean pseudothecia rating data were combined prior to statistical analyses. Data from each rating date were analyzed using the MIXED procedure (21).

\section{RESULTS}

Fungal isolates. All isolates characterized in this study $(n=77)$ were determined

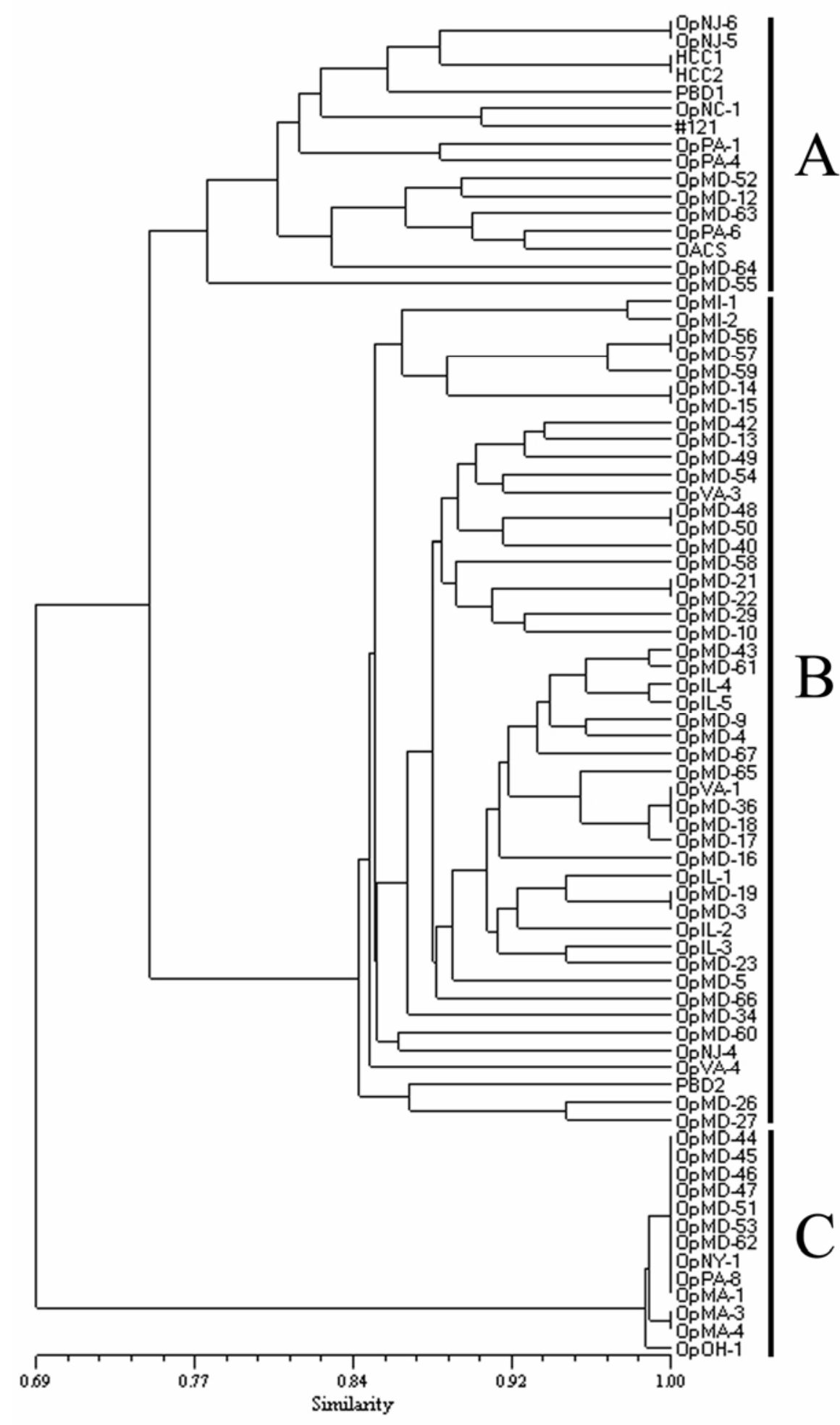

Fig. 3. Unweighted pair-group method with arithmetic mean dendrogram of 77 isolates of Ophiosphaerella agrostis collected from 21 different locations throughout the United States. Genetic distances were calculated by the SAHN similarity coefficient. to be $O$. agrostis by the use of speciesspecific oligonucleotide primers developed previously (13). Colony color varied when grown on PDA and incubated in the dark at $25^{\circ} \mathrm{C}$ for 10 days. Most isolates $(n=52)$ exhibited the typical rose-quartz or pink colony color previously described $(1,3,9,11)$ (Table 1, Fig. 1). The Ohio isolate $(\mathrm{OpOH}-1)$ typified the olive-gray or buff colony color observed in numerous isolates $(n=21)$. Three isolates (OpMD12, OpNC-1, and OpNJ-6) separated into a third mycelial color class, which appeared predominantly gray. $O$. agrostis isolate OpMD-10, which appeared as rose-quartz after the initial isolation (26 October 1998), grew more appressed to the agar surface and was beige or buff in color when removed from storage for DNA isolation.

AFLP analyses. Amplification of $O$. agrostis DNA using the primers EcoRI+AG and $M s e \mathrm{I}+\mathrm{C}$ resulted in a total of 97 bins (categorized DNA fragment) within the range of 64 to 411 bp (Fig. 2). The resulting matrix had 7,469 data points. Data were used to produce a similarity tree using both the SAHN and NJ method. The similarity tree produced using the SAHN method resulted in a similarity of $69 \%$ or higher (Fig. 3). The 77 isolates analyzed in this study separated into three distinct clades. Isolates belonging to clade $\mathrm{A}(n=$ $16)$ and clade B $(n=48)$ were highly variable and had similarities of $77 \%$ and $84 \%$, respectively. Clade A and clade B had 9 and 5 unique fragments, respectively, but all were polymorphic among isolates within each clade (Table 2). Little variation existed among isolates within clade $\mathrm{C}$ ( $n=$ 13), which were $99 \%$ similar. Clade $C$ had four unique fragments, and all were monomorphic among the isolates (Table 2). Molecular groupings of the 77 isolates were confirmed by analysis using the $\mathrm{NJ}$ method (data not shown).

Isolates separating into clade $\mathrm{A}$ included isolates collected from creeping bentgrass in $\mathrm{NJ}, \mathrm{MD}, \mathrm{PA}$, and $\mathrm{NC}$ and hybrid bermudagrass from TX. Colony color of isolates in this group was the most diverse of the three clades. Colony color ranged from rose-quartz to gray, and all three colony colors described previously were represented by isolates of clade A. The majority of isolates analyzed fit into clade $\mathrm{B}$, and included all of the isolates collected from VA, IL, and MI and a subset of isolates from NJ and MD. Additionally, isolates collected from both colonial and velvet bentgrass fit into clade B. Colony color of isolates within this group generally was similar to the original rose-quartz description of the pathogen. Two, OpNJ-4 and OpMD-10, out of 48 isolates, however, had unusual morphological characteristics. Isolate OpNJ-4 exhibited a gray/buff colony color and was similar in appearance to isolates described in clade C. Isolate OpMD-10, described above, varied from 
the original description at isolation and may have lost certain colony characteristics during storage.

Clade $\mathrm{C}$ included all isolates from MA, $\mathrm{NY}$, and $\mathrm{OH}$, a single isolate from PA, and several MD isolates collected from the University of Maryland Paint Branch Turfgrass Research Facility (PBTRF) in College Park (Fig. 3). A creeping bentgrass putting green at PBTRF had been inoculated with various isolates of $O$. agrostis, including OpOH-1, OpMD-9, and OpVA-1. Of the 13 isolates within clade $\mathrm{C}, 10$ were identical based on amplification with primers EcoRI+AG and MseI+C. Colony color (gray/buff) generally was identical for isolates separating into this group. Based on the DNA fingerprint using AFLP, colony color generally separated with each clade. Although isolates within each clade generally shared similar colony color (80\%), AMOVA revealed that color $(n=3$ : gray, gray/buff, rose-quartz) alone does not

Table 2. Polymorphic and monomorphic fragments unique to isolates within each of three clades based on unweighted pair-group method with arithmetic mean analyses of amplified fragment length polymorphisms of 77 Ophiosphaerella agrostis isolates

\begin{tabular}{|c|c|c|c|c|}
\hline Clade & $\begin{array}{c}\text { Locus } \\
\text { (bp) }\end{array}$ & $\begin{array}{l}\text { Fragment } \\
\text { morphology }\end{array}$ & $\begin{array}{l}\text { No. } \\
\text { isolates }\end{array}$ & Isolate(s) designation \\
\hline \multirow[t]{9}{*}{ A } & 378 & Polymorphic & 1 & OpMD-55 \\
\hline & 376 & Polymorphic & 1 & OpMD-64 \\
\hline & 254 & Polymorphic & 1 & OpMD-64 \\
\hline & 238 & Polymorphic & 1 & OpMD-64 \\
\hline & 203 & Polymorphic & 5 & $\begin{array}{l}\text { OACS , OpMD-52, OpMD-63, } \\
\text { OpMD- } 64, \text { OpPA- } 6\end{array}$ \\
\hline & 128 & Polymorphic & 5 & $\begin{array}{l}\text { OpMD-55, OpNJ-5, OpNJ-6, OpPA-1, } \\
\text { OpPa-4 }\end{array}$ \\
\hline & 107 & Polymorphic & 2 & OACS, OpMD-55 \\
\hline & 92 & Polymorphic & 3 & OACS, OpMD-64, OpPA-6 \\
\hline & 84 & Polymorphic & 3 & OACS, OpMD-55, OpMD-64 \\
\hline \multirow[t]{5}{*}{ B } & 403 & Polymorphic & 1 & PBD2 \\
\hline & 307 & Polymorphic & 2 & OpMD-66, OpVa-3 \\
\hline & 174 & Polymorphic & 2 & OpMD-26, OpMD-27 \\
\hline & 117 & Polymorphic & 13 & $\begin{array}{l}\text { OpIL-3, OpMI-1, OpMI-2, OpMD-14, } \\
\text { OpMD-10, OpMD-15, OpMD-23, } \\
\text { OpMD-29, OpMD-42, OpMD-56, } \\
\text { OpMD-57, OpMD-59, OpMD-66 }\end{array}$ \\
\hline & 80 & Polymorphic & 7 & $\begin{array}{l}\text { OpMD-13, OpMD-26, OpMD-27, } \\
\text { OpMD-40, OpMD-66, OpNJ-4, OpVA-4 }\end{array}$ \\
\hline \multirow[t]{4}{*}{$\mathrm{C}$} & 317 & Monomorphic & 13 & $\mathrm{All}^{\mathrm{a}}$ \\
\hline & 297 & Monomorphic & 13 & All \\
\hline & 224 & Monomorphic & 13 & All \\
\hline & 221 & Monomorphic & 13 & All \\
\hline
\end{tabular}

${ }^{\text {a }}$ Fragments of DNA unique to clade $\mathrm{C}$ were observed in all isolates (OpMD-44 to OpMD-47, OpMD51, OpMD-53, OpMD-62, OpNY-1, OpPA-8, OpMA-1, OpMA-3, OpMA-4, and OpOH-1). indicate genetic similarity among isolates (Table 3). The largest variation occurred within clade A, which shared colony characteristics from both clade $\mathrm{B}$ and $\mathrm{C}$.

$O$. agrostis isolates obtained from the same golf course generally were similar. Exceptions to this were observed in isolates collected from P. B. Dye Golf Club located in Urbana, MD, and from Honeybrook Golf Club located in Honeybrook, PA. The two isolates collected from P. B. Dye (PBD1 and PBD2) in 1998 separated into clades A and B. Similarly, isolates collected from Honeybrook in 1999 (OpPA-4) and 2000 (OpPA-8) separated into clades $\mathrm{A}$ and $\mathrm{C}$, respectively. The broad genetic diversity of $O$. agrostis isolates can be seen in the fingerprints obtained from AFLP analysis of isolates OpMD-48 to OpMD-67 (Fig. 3). These isolates were collected in October 2003 from the aforementioned PBTRF research green. As previously noted, between 1999 and 2003, the site had been inoculated with three different isolates including OpVA-1, OpMD-9, and OpOH-1. Of the 20 isolates collected, four separated into clade A, nine into clade $B$, and seven into clade $C$, illustrating the diversity of the pathogen within even a small geographic area. Of the isolates used to inoculate the site, OpMD-9 and OpVA-1 grouped into clade $\mathrm{B}$, while the Ohio isolate fit into clade C. Although several isolates collected from the research site in October 2003 grouped into clade A, none of the isolates used to inoculate the area separated into this group. Based on AMOVA analyses, isolates were not more similar to other isolates when comparisons were based on geographic region alone ( $n$ $=4:$ mid-Atlantic, midwest, northeast, south). Classification based on state of origin ( $n=7$ : IL, MA, MD, MI, PA, NJ, VA), however, revealed that isolates from the same state had less genetic diversity (Table 3).

Pseudothecia production. Pseudothecia production was monitored using a subset of isolates from the AFLP analysis with varying colony colors (Fig. 1). Although pseudothecia development initially was more rapid in study two than in study one, the total number of pseudothecia produced for each isolate was similar between experiments. On individual rating dates, there were significant differences in pseudothecia production among the isolates $(P$ $\leq 0.0159$ ). After 4 days of incubation at $25^{\circ} \mathrm{C}$ in constant light, pseudothecia began to develop on tall fescue seeds infested with isolates OpMD-9, OpMI-1, OpMA-4, OpNY-1, and OpOH-1 (Fig. 4). At the same time, no mature ascospores were found within any developing pseudothecia. Ascospore maturation was determined by the presence of fully developed ascospores with visible septations. Following 6 days of incubation (6 DOI), ascospores inside developing pseudothecia generally were immature; however, mature ascospores were found within pseudothecia from isolates OpMD-9, OpMI-1, and OpMA-4. These results were similar to a previous study in which pseudothecia development began in as little as 4 days and mature ascospores were present within 1 week of incubation (12). By 18 DOI, pseudothecia

Table 3. Analyses of molecular variance of pair-wise distances for Ophiosphaerella agrostis isolates based on classes of color, geographic location (state or region), and pseudothecia production

\begin{tabular}{|c|c|c|c|c|c|c|}
\hline Class & Source of variation & df & Sum of squares & Mean squares & Total variance $(\%)$ & $\boldsymbol{P}$ \\
\hline Color & $\begin{array}{l}\text { Among populations } \\
\text { Within populations }\end{array}$ & $\begin{array}{c}2 \\
74\end{array}$ & $\begin{array}{r}98.0 \\
682.2\end{array}$ & $\begin{array}{r}49.0 \\
9.2\end{array}$ & $\begin{array}{l}20 \\
80\end{array}$ & 0.01 \\
\hline $\begin{array}{l}\text { Geographic location } \\
\text { State }\end{array}$ & $\begin{array}{l}\text { Among populations } \\
\text { Within populations }\end{array}$ & $\begin{array}{c}6 \\
66\end{array}$ & $\begin{array}{l}292.7 \\
492.3\end{array}$ & $\begin{array}{r}48.8 \\
6.5\end{array}$ & $\begin{array}{l}53 \\
47\end{array}$ & 0.01 \\
\hline Region & $\begin{array}{l}\text { Among populations } \\
\text { Within populations }\end{array}$ & $\begin{array}{c}3 \\
49\end{array}$ & $\begin{array}{r}83.5 \\
416.0\end{array}$ & $\begin{array}{r}27.8 \\
8.5\end{array}$ & $\begin{array}{l}20 \\
80\end{array}$ & 0.01 \\
\hline Pseudothecia production & $\begin{array}{l}\text { Among populations } \\
\text { Within populations }\end{array}$ & $\begin{array}{l}2 \\
5\end{array}$ & $\begin{array}{l}54.0 \\
24.3\end{array}$ & $\begin{array}{r}27.0 \\
4.9\end{array}$ & $\begin{array}{l}63 \\
37\end{array}$ & 0.01 \\
\hline
\end{tabular}

\footnotetext{
${ }^{\text {a }}$ Geographic location analyses were as follows: state = IL, MA, MD, MI, PA, NJ, and VA; region = mid-Atlantic, midwest, northeastern, and southern
} United States. 
production of isolates OpMD-9 and OpMI1 leveled off as maximum pseudothecia production was approached. Moderate pseudothecia production was observed from isolates OpMA-4, OpOH-1, and OpNY-1. Both isolates collected from golf courses in NJ (OpNJ-4 and OpNJ-6) produced few (first study; Fig. 4A) or no (second study; Fig. 4B) pseudothecia. Except for isolates OpNJ-4 and OpNC-1, mature ascospores were found within pseudothecia from all isolates by the final rating date of the first study (30 DOI). In the second study, isolates OpNJ-4, OpNJ-6, and OpNC-1 did not produce pseudothecia.

Pseudothecia production from individual isolates generally could be associated with colony color and genetic diversity clades. With the exception of OpNJ-4, isolates belonging to clade B (OpMD-9 and OpMI-1) had the most rapid and greatest number of pseudothecia produced.
Isolates OpMD-9 and OpMI-1 were the only isolates in this experiment that exhibited the characteristic rose-quartz colony color when grown on PDA. Although isolate OpNJ-4 grouped into clade B based on AFLP fingerprints, it exhibited the greatest variation in colony color when compared with the other 47 isolates within the genetic clade. Moderate numbers of pseudothecia were produced by isolates OpMA-4, OpOH-1, and OpNY-1. Separating into clade $\mathrm{C}$, these aforementioned isolates were most closely related in colony color as well as in genetic similarity. Representing clade A, isolates OpNJ-6 and OpNC-1 exhibited little or no pseudothecia production. Sharing a similar gray colony color, but belonging to clade $\mathrm{B}$, isolate $\mathrm{OpNJ}-4$ also produced few pseudothecia. The AMOVA analyses found that there was greater genetic similarity among isolates that had similar pseudothecia production
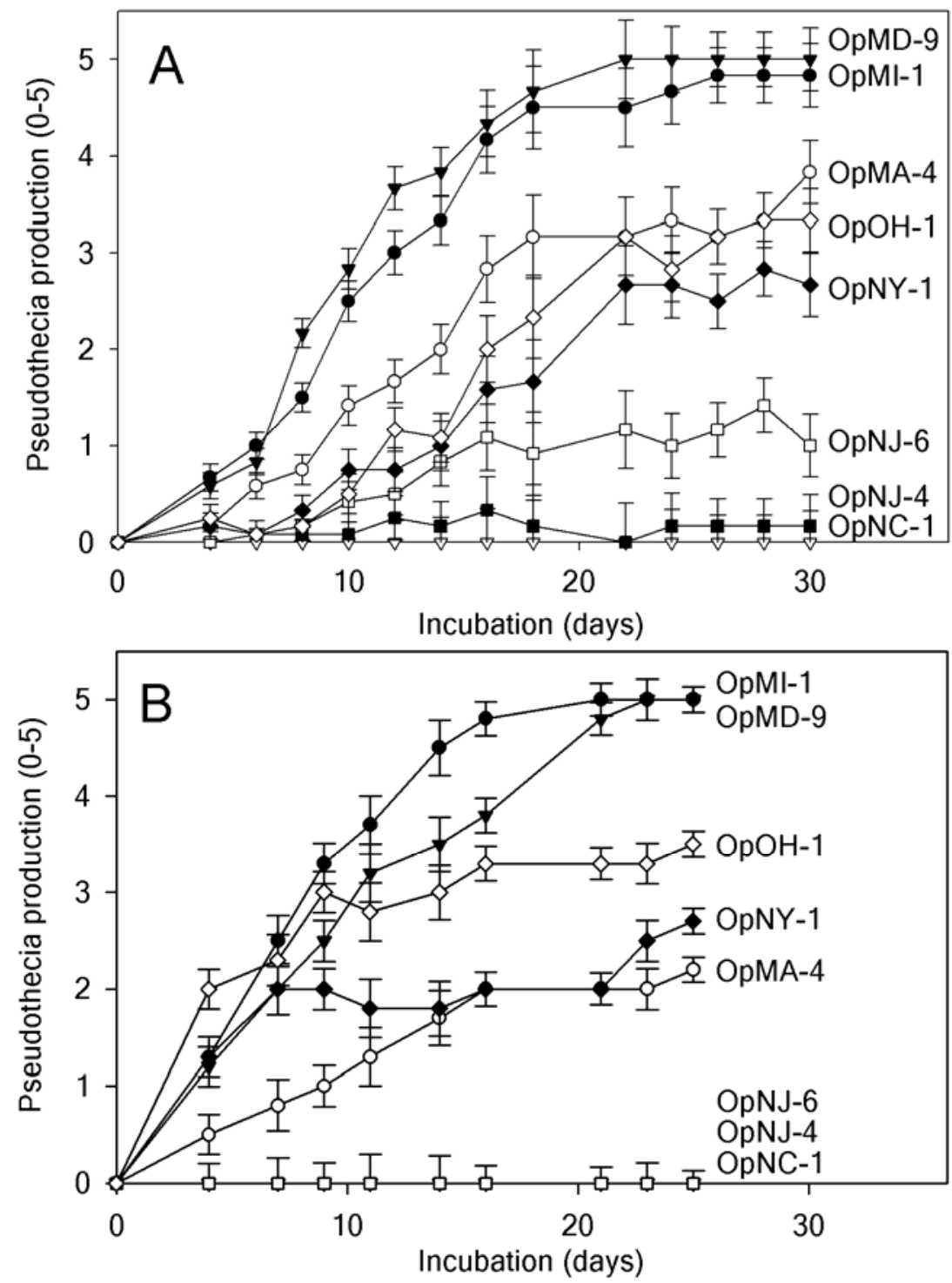

Fig. 4. Pseudothecia development from various isolates of Ophiosphaerella agrostis after incubation at $25^{\circ} \mathrm{C}$ in constant light for 25 to 30 days. The study was repeated twice and replications are shown as $\mathbf{A}$ and $\mathbf{B}$. Pseudothecia were rated on a 0 to 5 scale, where $0=$ none, $3=11$ to 15 , and $5=$ more than 21 pseudothecia with necks partially embedded in tall fescue seed. Error bars represent standard errors of the differences among isolates on individual rating dates $(P \leq 0.05)$.

than among all isolates $(n=3$ : high, moderate, low) (Table 3). Since only eight isolates were used in this experiment, quantifying pseudothecia production with additional isolates may help confirm whether sexual reproduction accounted for the large variation among $O$. agrostis isolates.

\section{DISCUSSION}

Genetic variation among $O$. agrostis isolates based on AFLP fingerprinting is highly diverse. Based on the results of AFLP analysis using primers EcoRI+AG and $M s e \mathrm{I}+\mathrm{C}, O$. agrostis separated into three distinct clades. The most divergent group, with a similarity of $69 \%$, included 13 isolates from six different locations within five different states. Câmara et al. (1) found similar divergence of the Ohio isolate within a subset of $O$. agrostis isolates. Divergence among isolates within the Ohio group (Clade C), however, was very low with a similarity of $99 \%$, with 10 isolates being identical. Previous observations with a single isolate from this group $(\mathrm{OpOH}-1)$ indicate many differences between this isolate and others included in this study. The Ohio isolate was the only one to produce pseudothecia on PDA plates (9), the only one to survive longterm storage on desiccated filter paper (J. E. Kaminski, unpublished), and the only one to show a reduced sensitivity to the fungicide iprodione (9). Although these only were observations, they may be associated with the pathogen's ability to enhance its survival. The final two groups were $75 \%$ similar, and divergence within clades A and B was high at $77 \%$ and $84 \%$, respectively. Although Câmara et al. (1) reported greater similarity (87\%) among a subset of $O$. agrostis isolates $(n=12)$, the analyses also included other Ophiosphaerella spp. as outliers, which may have increased the similarity among the $O$. agrostis isolates. Additionally, the aforementioned study only scored bands between 62 and 266 bp, while analyses performed within this study only included isolates of $O$. agrostis and measured fragments as large as $411 \mathrm{bp}$. It is likely that differences in the DNA separation technique, subjectivity in scoring DNA fragments, addition of Ophiosphaerella spp. other than $O$. agrostis, and possibly other factors resulted in varying levels of genetic diversity among the two studies. Regardless, examination of the dendrogram presented by Câmara et al. (1) suggests a total of three clades with one, two, and nine isolates in each. Unfortunately, many of the isolates used in the original examination of $O$. agrostis were lost and not included in this study. The isolates that were included (OpVA-1, OpMD-9, OpMD-4, OpMD-5, OpIL-1, OpPA-1, and OpOH-1), however, generally fit into similar groupings.

Isolates collected from a single location in College Park, MD, separated into all 
three clades, despite inoculation of the site with isolates from only two (i.e., B and C) of the clades. The reason for this segregation, however, remains unclear. Different strains of the pathogen may have been introduced through seed or ascospores carried to the site naturally by air currents. Other possible explanations could be the sexual recombination of different $O$. agrostis strains through outcrossing. Homothallic, filamentous ascomycetes have been shown to have either one or two mating genes (MAT) with two alternative forms (MAT1-1 and MAT1-2) known as idiomorphs $(6,18)$. Although the mating genes of $O$. agrostis are unknown, both mating types have been detected in $O$. korrae (7). Despite having both mating type genes, other homothallic fungi are capable of both selfing and outcrossing. In particular, isolates of Gibberella zeae (Schwein.) Petch, which carry both MAT11 and MAT1-2 in the same nucleus, have been shown to outcross (16). Additionally, recent studies involving the differential deletion of each idiomorph within G. zeae resulted in a self-sterile strain (16). In this case, the homothallic G. zeae was modified through molecular processes to behave as a strictly heterothallic fungus. The ability of the mutated strain of G. zeae to outcross with tester isolates was retained, indicating the requirement for the presence of both MAT idiomorphs to be self fertile. Varying levels of pseudothecia production (i.e., sexual reproduction) have been observed among our isolates of $O$. agrostis.

Sexual reproduction plays an important role in the survival and pathogenicity of many plant pathogens. The ability to sexually reproduce is an evolutionary process that often results in increased pathogen fitness and survival. Genetic diversity of isolates also may assist in the important adaptation of the pathogen into new or different geographic regions. Populations that maintain high levels of similarity within a specific geographic region, and also are similar to a select group of isolates from a completely different geographic area, may indicate that the pathogen was introduced into both regions from the same or similar genetic source. For example, $O$. agrostis isolates within clade $\mathrm{C}$ showed high similarity ( $\geq 99 \%$ ), when compared to isolates within clade A $(77 \%)$ and B $(84 \%)$. Despite this similarity, isolates within clade $\mathrm{C}$ were collected from various regions of the United States including Maryland, Massachusetts, New York, Ohio, and Pennsylvania. These results may indicate that the pathogen was introduced from a similar source, such as from seed grown in the same region. Raffle and Hsiang (19), however, reported no genetic variation among single ascospore sibling progeny of $O$. korrae using random amplified polymorphic DNA analysis. This information may suggest that multiple generations from a single $O$. agrostis isolate would retain a higher genetic similarity. Hence, high levels of genetic diversity among isolates may have occurred from either outcrossing of $O$. agrostis strains, parasexuality, genetic mutations, or a combination of the three.

In addition to the polymorphic DNA patterns found among $O$. agrostis isolates, previous research revealed differences in rDNA sequences in the ITS region. The ITS region is conserved within species of a particular genus, and sequences from this region are frequently used in determining the phylogeny of fungi based on molecular sequencing, rather than morphological characteristics. The validity of this approach, however, has been questioned, and multiple loci sequencing may be necessary to accurately determine the phylogeny of both new and existing pathogens. The single base pair insertion found by Câmara et al. (1) in the ITS2 region of OpOH-1 suggests that multiple gene sequencing may be necessary to accurately categorize both new and existing pathogens into the correct genus and species. Sequence variation from multiple loci may reveal further differences among isolates separating into each of the three clades and potentially clarify the placement of these isolates within $O$. agrostis. Based on the aforementioned DNA fingerprint analysis, a total of 12 additional isolates exhibited strong similarities to isolate $\mathrm{OpOH}-1$. The entire group (clade C), however, only had a $69 \%$ similarity to the other $O$. agrostis isolates $(n=65)$ examined. The strong similarity among a small subset of isolates may indicate possible divergence to a new species of Ophiosphaerella other than O. agrostis.

Although the actual sexual compatibility of this pathogen remains unknown, $O$. agrostis is genetically diverse. Despite the examination of numerous isolates in this study, the anamorph of $O$. agrostis has not been reported and the pathogen appears to exist exclusively in its teleomorphic state. Within the genus Ophiosphaerella, an anamorph only has been reported for $O$. herpotricha (30). This conidial state rarely has been reported, and the genetic connection has been questioned $(1,29)$.

\section{ACKNOWLEDGMENTS}

We are grateful for the financial support for this study by the United States Golf Association and for the technical assistance provided by Eva Claire Synkowski. We thank B. Clarke, R. Kane, N. Tisserat, and $\mathrm{H}$. Wetzel for providing isolates for this study.

\section{LITERATURE CITED}

1. Câmara, M. P. S., O’Neill, N. R., van Berkum, P., Dernoeden, P. H., and Palm, M. E. 2000. Ophiosphaerella agrostis sp. nov. and its relationship to other species of Ophiosphaerella. Mycologia 92:317-325.

2. Crahay, J. N., Dernoeden, P. H., and O'Neill, N. R. 1988. Growth and pathogenicity of Leptosphaeria korrae in bermudagrass. Plant Dis. 72:945-949.

3. Dernoeden, P. H., O'Neill, N. R., Câmara, M. P. S., and Feng, Y. 1999. A new disease of
Agrostis palustris incited by an undescribed species of Ophiosphaerella. Plant Dis. 83:397.

4. Dernoeden, P. H., Zhang, M., and Wetzel, H C. 1995. First report of necrotic ring spot (Leptosphaeria korrae) in creeping red fescue in Maryland. Plant Dis. 79:966.

5. Endo, R. M., Ohr, H. D., and Krausman, E. M. 1985. Leptosphaeria korrae, a cause of the spring dead spot disease of bermudagrass in California. Plant Dis. 69:235-237.

6. Glass, N. L., Metzenberg, R. L., and Raju, N B. 1990. Homothallic Sordariaceae from nature: The absence of strains containing only a mating-type sequence. Exp. Mycol. 14:274289.

7. Hsiang, T., Chen, F., and Goodwin, P. H. 2003. Detection and phylogenetic analysis of mating type genes of Ophiosphaerella korrae. Can. J. Bot. 81:301-315.

8. Huff, D. R., Peakall, R., and Smouse, D. E. 1993. RAPD variation within and among populations of outcrossing buffalograss [Buchloë dactyloides (Nutt.) Engelm.]. Theor. Appl. Genet. 86:927-934.

9. Kaminski, J. E. 2001. Growth, pseudothecia production, and ascospore germination of Ophiosphaerella agrostis and cultivar susceptibility and geographic distribution of bentgrass dead spot. M.S. thesis. Department of Natural Resource Sciences and Landscape Architecture, University of Maryland, College Park.

10. Kaminski, J. E. 2004. Biology of Ophiosphaerella agrostis, epidemiology of dead spot, and a molecular description of the pathogen. Ph.D. diss. University of Maryland, College Park.

11. Kaminski, J. E., and Dernoeden, P. H. 2002. Geographic distribution, cultivar susceptibility, and field observations on bentgrass dead spot. Plant Dis. 86:1253-1259.

12. Kaminski, J. E., Dernoeden, P. H., O’Neill, N. R., and Momen, B. 2002. Reactivation of bentgrass dead spot and growth, pseudothecia production, and ascospore germination of Ophiosphaerella agrostis. Plant Dis. 86:12901296.

13. Kaminski, J. E., Dernoeden, P. H., O'Neill, N. R., and Wetzel, H. C., III. 2005. A PCR-based method for the detection of Ophiosphaerella agrostis in creeping bentgrass. Plant Dis. 89:980-985.

14. Krausz, J. P., White, R. H., Tisserat, N. A., and Dernoeden, P. H. 2001. Bermudagrass dead spot: A new disease of bermudagrass caused by Ophiosphaerella agrostis. Plant Dis. 85:1286.

15. Landschoot, P. J. 1996. First report of necrotic ring spot on Poa annua putting greens in Pennsylvania. Plant Dis. 80:712.

16. Lee, J., Lee, T., Lee, Y.-W., Yun, S.-H., and Turgeon, B. G. 2003. Shifting fungal reproductive mode by manipulation of mating type genes: Obligatory heterothallism of Gibberella zeae. Mol. Microbiol. 50:145-152.

17. Peakall, R., and Smouse, P. E. 2001. GenAlEx V5: Genetic Analysis in Excel. Population genetic software for teaching and research. Australian National University, Canberra, Australia. http://www.anu.edu.au/BoZo/GenAlEx.

18. Pöggeler, S. 1999. Phylogenetic relationships between mating-type sequences from homothallic and heterothallic ascomycetes. Curr. Genet. 26:222-231.

19. Raffle, V. L., and Hsiang, T. 1998. Low level of DNA polymorphisms in isolates of Leptosphaeria korrae pathogenic on Poa pratensis. Can. J. Plant Pathol. 20:48-54.

20. Saitou, N., and Nei, M. 1987. The neighborjoining method: A new method for reconstructing phylogenetic trees. Mol. Biol. Evol. 4:406425.

21. SAS Institute 2000. SAS OnlineDoc. Version 8. SAS Institute, Cary, NC. 
22. Saunders, J. A., Mischke, S., and Hemeida, A. A. 2001. The use of AFLP techniques for DNA fingerprinting in plants. Beckman Coulter Application Notes A1910A:1-9.

23. Saunders, J. A., Mischke, S., and Hemeida, A. A. 2002. Identification of Theobroma cacao germplasm by AFLP-generated molecular markers. CEQuence 2:5-8.

24. Smith, A. M. 1965. Ophiobolus herpotrichus a cause of spring dead spot in couch turf. Agric. Gazette N.S.W. 76:753-758.

25. Sneath, P. H. A., and Sokal, R. R. 1973. Numerical Taxonomy. Freeman, San Francisco.

26. Tisserat, N. A., Pair, J. C., and Nus, A. 1989. Ophiosphaerella herpotricha, a cause of spring dead spot of bermudagrass in Kansas. Plant Dis. 73:933-937.

27. Viji, G., Uddin, W., O’Neill, N. R., Mischke, S., and Saunders, J. A. 2004. Genetic diversity of Sclerotinia homoeocarpa isolates from turfgrasses from various regions in North America. Plant Dis. 88:1269-1276.

28. Vos, P., Hogers, R., Bleeker, M., Reijans, M., van de Lee, T., Hornes, M., Frijters, A., Pot, J., Peleman, J., Kuiper, M., and Zabeau, M. 1995. AFLP: A new technique for DNA fingerprinting. Nucleic Acids Res. 23:4407-4414.

29. Walker, J. 1980. Gaeumannomyces, Linocarpon, Ophiobolus and several other genera of scolecospored ascomycetes and Phialophora condial states, with a note on hyphopodia. Mycotaxon 11:1-129.

30. Webster, J., and Hudson, H. J. 1957. Graminicolous Pyrenomycetes VI. Conidia of Ophiobolus herpotrichus, Leptosphaeria luctuosa, L. fuckelii, L. pontiformis and L. eustomoides. Trans. Br. Mycol. Soc. 40:509-522.

31. Wetzel, H. C., III, Hulbert, S. H., and Tisserat, N. A. 1999. Molecular evidence for the presence of Ophiosphaerella narmari n. comb., a cause of spring dead spot of Bermuda grass, in North America. Mycol. Res. 103:981-989.

32. Worf, G. L., Stewart, J. S., and Avenius, R. C. 1986. Necrotic ring spot disease of turfgrass in Wisconsin. Plant Dis. 70:453-458. 